\title{
The new results of experimental studies of fission products release from spent nuclear fuel of the icebreaker "Lenin" reactor dumped in the Kara Sea
}

\author{
V. Soyfer ${ }^{1}$, V. Goryachev ${ }^{1}$, A. Salyuk ${ }^{1}$, O. Dudarev ${ }^{1}$, D. Andreev², \\ A. Gaiduchenko ${ }^{2}$, I. Barabanov ${ }^{3}$ and E. Yanovich ${ }^{3}$ \\ 1I. Il'ichev Pacific Oceanological Institute, FEB RAS, 690041 Vladivostok, Russia \\ ${ }^{2}$ National Research Centre "Kurchatov Institute", 123182 Moscow, Russia \\ 3 Institute for Nuclear Research RAS, 117312 Moscow, Russia
}

\begin{abstract}
The new technologies were developed for spent nuclear fuel (SNF) condition operative monitoring and search for the lost objects with SNF at the sea bottom using $\mathrm{Kr}-85$. The new paradigm of sea radioecology based on extensive research was proposed. The investigations include a preliminary experimental study of kinetics of fission products (Kr-85 and Cs-137) release from SNF, a subsequent expedition to the Arctic, as well as modeling radionuclides transfer in a near-bottom layer by means of fractal formalism using hydrological data on the expedition area [1, 2]. Series of original experimental studies on $\mathrm{Kr}-85$ and Cs-137 release from SNF during corrosion in sea water were conducted in 2002-2010. Time dependence of fission products (FP) release was measured in laboratory under conditions typical of a near-bottom water layer in the Novaya Zemlya Basin. Another important result was received during the expedition to the Arctic in the fall of 2000. The H-3 anomaly was recognized in the surface layer of the Kara Sea in the Novaya Zemlya Basin ( $228 \pm 9.1$ TU vs.10-15 TU in the Arctic on average!). This anomaly is located 100 miles south from the dumped reactor of atomic icebreaker "Lenin". So it can be caused by SNF from the reactors of icebreaker "Lenin" or nuclear submarine K-140.
\end{abstract}

\section{EXPERIMENTAL STUDY ON KINETICS OF FISSION PRODUCTS RELEASE}

\subsection{Introduction}

The objects with unloaded spent nuclear fuel (SNF) at the sea bottom may cause environmental pollution (for example, in the Arctic) when protective barriers of the SNF assembly are untight. This problem remains the main scientific problem of marine radioecology. At present, methods of episodic radioecological monitoring and numerical simulation cannot give reliable estimates of the radioactive contamination level of the seabed and determine the radiation dose. There is no method available for determination of the beginning of fission products (FP) mass release from SNF to sea water when protective barriers are destroyed. There is the lack of knowledge for time dependence of the processes that influence on SNF safety at the sea bottom is important. The new approach to the problem was developed. It allows to give a conservative estimation of risk of the accident and possible effects on natural and anthropogenic environment in sites of catastrophe and dumping regions of nuclear objects with SNF. Results of the experimental research of FP (Kr-85 and Cs-137) release from the spent oxide nuclear fuel during interaction with sea water are presented. Experimental conditions simulate a zone in dumping regions of nuclear reactors cores.

\section{2 perimental studies on krypton-85 and cesium-137 release from spent nuclear fuel}

Series of experimental studies on time dependence of $\mathrm{Kr}-85$ and Cs-137 release from SNF during corrosion in sea water were carried out in NRC "Kurchatov Institute" in 2002-2010 [3, 4]. 


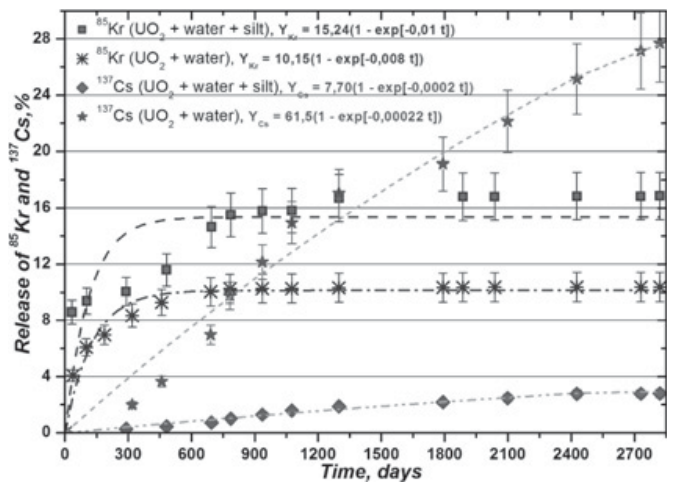

Figure 1. Cs-137 and $\mathrm{Kr}-85$ integral release (\%) from $\mathrm{UO}_{2}$ spent nuclear fuel after 2800 days.

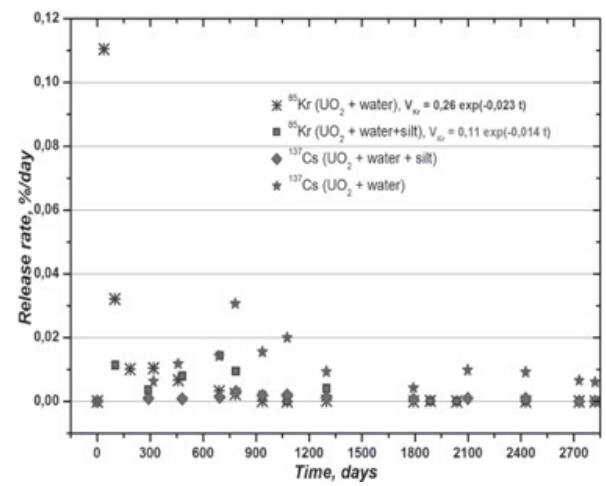

Figure 2. Cs-137 and $\mathrm{Kr}-85$ release rates (\%/day) from $\mathrm{UO}_{2}$ spent nuclear fuel after 2800 days.

Experimental conditions simulated parameters of a near-bottom water layer in the Novaya Zemlya Basin. Measurements of Kr-85 release (by sampling the gas) and Cs-137 release (by measuring the specific gamma-activity of water samples) were periodically performed. The difference in the half-lives of Kr-85 (10.6 years) and Cs-137 (30 years) was taken into account in FP release calculation. Fission products release values are given in $\%$ of the initial accumulated amount. The experiment duration has made more than 2800 days.

\subsubsection{Experimental data on the SNF corrosion process in sea water after 2800 days of the experiment}

Estimations have shown that the initial specific activities of $\mathrm{Kr}-85$ and Cs-137 in the samples were $4.0310^{8} \mathrm{~Bq} / \mathrm{g}$ and $5.610^{9} \mathrm{~Bq} / \mathrm{g}$ respectively (in each SNF piece) [3]. The specific activity of Cs-137 in the samples was measured directly by gamma-spectrometry and used to calculate the burnup level. The specific activity of $\mathrm{Kr}-85$ was calculated on the basis of the estimated burnup; it was not taken into account that some portion of $\mathrm{Kr}$ released from fuel under the cladding during irradiation. The results of the experiment are shown below. The experimental dependences of $\mathrm{Kr}-85$ and $\mathrm{Cs}-137$ release are presented in Figure 1. The calculated dependences of release rate are shown in Figure 2. The error band of $10 \%$ is also shown.

\subsubsection{Approximation of the experimental data}

Time dependence of fission products release is an exponential function that reaches saturation (assuming that $100 \%$ of fission gas is released for infinite period of time, if decay is not taken into account). Thus, 
Table 1. Maximum integral release of fission products (\%) from spent $\mathrm{UO}_{2}$ fuel.

\begin{tabular}{|l|c|c|c|c|c|c|c|c|}
\hline \multirow{2}{*}{ Nuclide } & \multicolumn{8}{|c|}{ Duration, days } \\
\cline { 2 - 9 } & 200 & 365 & 730 & 1460 & 2000 & 2400 & 2700 & 2800 \\
\hline Kr-85 & 12.0 & 14.7 & 15.3 & 16.8 & 16.8 & 16.8 & 16.8 & 16.8 \\
\hline Cs-137 & 2.0 & 3.0 & 9.1 & 17.9 & 21.8 & 25.1 & 27.1 & 27.7 \\
\hline
\end{tabular}

the function that approximates the experimental release curve is:

$$
\mathrm{Y}=\mathrm{A} \cdot\left(1-\exp \left[-\mathrm{K}_{\mathrm{V}} \cdot \mathrm{t}\right]\right)
$$

where

A - total release for infinite period of time (theoretically 100\%); it can be determined from available experimental data on kinetics;

$\mathrm{K}_{\mathrm{V}}-$ constant which determines the release rate;

$\mathrm{t}$ - time since the beginning of monitoring.

Release rate can be defined as the first derivative of release as a function of time:

$$
\left.\mathrm{V}=\mathrm{dY} / \mathrm{dt}=\mathrm{A} \cdot \mathrm{K}_{\mathrm{V}} \cdot \exp \left[-\mathrm{K}_{\mathrm{V}} \cdot \mathrm{t}\right]\right)
$$

So the release rate also has exponential dependence. However you can see that approximating curves (1) and experimental points do not converge very well. This may be due to both measurement errors and uncontrolled experimental factors (e.g., changes in temperature result in altered kinetics of release because of Boltzmann factor $\exp (-\mathrm{Qdt} / \mathrm{kT}))$. Difference between experimental and theoretical (2) release rates can be also explained by the same factors. For example, release rate of Cs-137 slightly increased in the interval of 700-800 days that could indicate a change in conditions of the experiment (e.g., temperature of water). It is worth noting that $\mathrm{Kr}-85$ release rate is almost constant and close to zero, while Cs-137 release rate remains higher and increases. It can be explained by the facts that halflife for Cs-137 is almost 3 times higher than for $\mathrm{Kr}-85$ (30.1 vs. 10.7 years) and Cs-137 yield per one U fission is almost 20 times higher $(6.2 \%$ vs. $0.286 \%)$.

It can be seen that $\mathrm{Kr}-85$ release rate considerably exceeds $\mathrm{Cs}-137$ release rate in the initial period of time (Fig. 2). It was confirmed that $\mathrm{Kr}-85$ can be used as an early leakage indicator from the untight $\mathrm{SNF}$ assemble in dumping regions. However, it was observed that $\mathrm{Kr}-85$ release curve reaches saturation, while Cs-137 release rate is almost constant. Average release rate of $\mathrm{Kr}-85$ was $0.015 \%$ per day for the whole experiment; average release rate of Cs- 137 was $0.001 \%$ per day for water with silt and $0.01 \%$ for clean water.

The new data allow to estimate the maximum integral release of all radionuclides from the SNF at the bottom of the Novaya Zemlya Basin. Total release of all FP can be determined using results of Cs-137 isotope activity measurements in the given sample. Then this value can be recalculated to the weight of all fission products in the sample using a well-known distribution of the fission fragments. Values of maximum integral release of $\mathrm{Kr}-85$ and $\mathrm{Cs}-137$ are presented in Table 1 for different periods of time.

\section{TRITIUM RADIO ECOLOGY STUDY OF THE RUSSIAN ARCTIC SEAS}

\subsection{Introduction}

Use of tritium as a qualitative tracer in oceanology and hydrology of land waters is widely known (see for example [5]). Investigations of the process of its release to the environment are rather limited. Tritium is produced as a result of uranium ternary fission during irradiation in the reactor (this fact was known in 1959-1960 [6, 7]). During reactor irradiation one H-3 atom is produced per $(1.05 \pm 0.09) \times 10^{4}$ fission events [7]. Irradiated uranium fuel contains tritium as a gas phase $(25 \%)$ and in the form of tritium water 


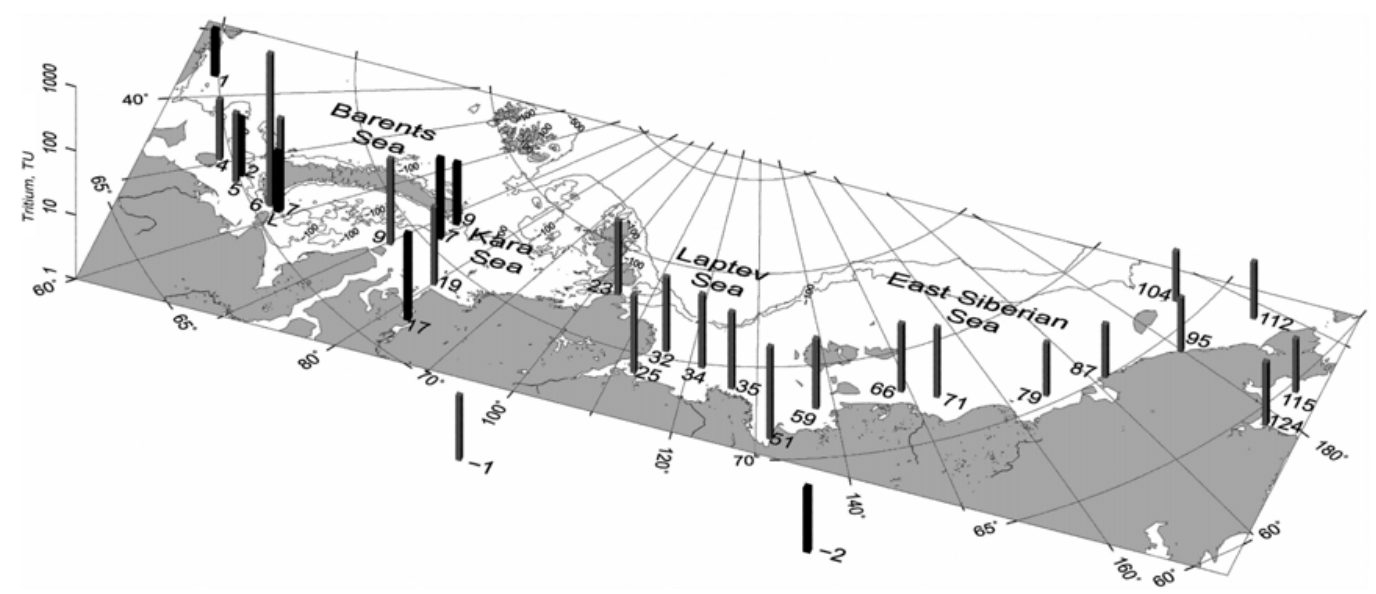

Figure 3. Map of Tritium distribution in Arctic Seas of Russia. 1) Expedition 2000. 2) Expedition 2003. Digits on the map are the stations numbers (see Table 2).

Table 2. Results of tritium measurements in Russian Arctic Seas. R/V "Nikolay Kolomiytsev" 2000. Tritium concentration was resulted for 01.09.2000.

\begin{tabular}{|c|c|c|c|c|c|c|c|}
\hline & & & & Depth & $\mathrm{T}$ & $\mathrm{S}$ & ${ }^{3} \mathrm{H}$ \\
\hline Sta. No & Date & $\varphi$ & $\lambda$ & $\mathrm{H}(\mathrm{m})$ & ${ }^{\circ} \mathrm{C}$ & $\%$ & $\mathrm{TU} \pm 2 \sigma$ \\
\hline 4 & 18.08 .00 & $69^{\circ} 33^{\prime} 42^{\prime \prime N}$ & $49^{\circ} 17^{\prime} 24^{\prime \prime} \mathrm{E}$ & 21 & 7.43 & 33.0 & $8.4 \pm 1.5$ \\
\hline 5 & 18.08 .00 & $69^{\circ} 51^{\prime} 10^{\prime \prime N}$ & $52^{\circ} 58^{\prime} 51^{\prime \prime E}$ & 71 & 9.66 & 30.3 & $11.5 \pm 1.6$ \\
\hline 6 & .08 .00 & $70^{\circ} 40^{\prime} 13^{\prime \prime} \mathrm{N}$ & $57^{\circ} 40^{\prime} 49^{\prime \prime} \mathrm{E}$ & 32 & 4.27 & 30.4 & $228 \pm 9.1$ \\
\hline 6 & \multicolumn{6}{|c|}{ Direct measurement (not enriched sample) } & $200 \pm 27$ \\
\hline 7 & 19.08 .00 & $70^{\circ} 55^{\prime} 12^{\prime \prime} \mathrm{N}$ & $58^{\circ} 54^{\prime} 42^{\prime \prime} \mathrm{E}$ & 211 & 7.15 & 31.8 & $27.5 \pm 2.8$ \\
\hline 9 & 20.08 .00 & $73^{\circ} 48^{\prime} 34$ & $70^{\circ} 09^{\prime} 20^{\prime \prime} \mathrm{E}$ & 21 & 6.44 & 13.0 & $20.9 \pm 2.9$ \\
\hline 19 & .08 .00 & $73^{\circ}$ & $80^{\circ} 00^{\prime} 22^{\prime \prime} \mathrm{E}$ & 3 & 3.98 & 20.9 & $15.8 \pm 2.2$ \\
\hline 23 & .08 .00 & $77^{\circ} 4$ & $4^{\prime} 29 " \mathrm{E}$ & 5 & 2.39 & 25.8 & $13.6 \pm 3.0$ \\
\hline 25 & .08 .00 & $74^{\circ} 01^{\prime} 55^{\prime \prime} \mathrm{N}$ & $112^{\circ} 42^{\prime} 50^{\prime \prime} \mathrm{E}$ & 20 & 2.9 & 13.19 & $15.5 \pm 2.2$ \\
\hline 32 & .08 .00 & $75^{\circ} 27^{\prime} 39^{\prime \prime} \mathrm{N}$ & $116^{\circ} 02^{\prime} 53^{\prime \prime E}$ & 19 & 2.34 & 24.81 & $14.1 \pm 1.4$ \\
\hline 34 & .08 .00 & $74^{\circ} 51^{\prime} 60^{\prime \prime N}$ & $121^{\circ} 56^{\prime} 57^{\prime \prime} \mathrm{E}$ & 18 & 1.87 & 26.4 & $13.5 \pm 2.2$ \\
\hline 35 & .08 .00 & $73^{\circ} 52^{\prime} 39^{\prime \prime} \mathrm{N}$ & $126^{\circ} 33^{\prime} 20^{\prime \prime} \mathrm{E}$ & 16 & 1.51 & 25.4 & $15.3 \pm 3.4$ \\
\hline 51 & .09 .00 & $71^{\circ} 13^{\prime} 00^{\prime \prime N}$ & $131^{\circ} 43^{\prime} 00^{\prime \prime} \mathrm{E}$ & 11 & 7.28 & 2.5 & $26.5 \pm 2.7$ \\
\hline 59 & .09 .00 & $72^{\circ} 44^{\prime} 50^{\prime \prime N}$ & $137^{\circ} 39^{\prime} 29^{\prime \prime} \mathrm{E}$ & 23 & 2.67 & 17.9 & $11.9 \pm 1.4$ \\
\hline 66 & 5.09 .00 & $73^{\circ} 09^{\prime} 29^{\prime \prime} \mathrm{N}$ & $142^{\circ} 21^{\prime} 08^{\prime \prime} \mathrm{E}$ & 12 & 1.95 & 20.5 & $11.1 \pm 2.4$ \\
\hline 71 & 7.09 .00 & $72^{\circ} 16^{\prime} 20^{\prime \prime} \mathrm{N}$ & $152^{\circ} 56^{\prime} 23^{\prime \prime} \mathrm{E}$ & 16 & 1.82 & 20.0 & $11.9 \pm 2.4$ \\
\hline 79 & 09.09 .00 & $70^{\circ} 30^{\prime} 48^{\prime \prime N}$ & $164^{\circ} 32^{\prime} 18^{\prime \prime} \mathrm{E}$ & 24 & 1.4 & 28.4 & $6.5 \pm 1.5$ \\
\hline 87 & 10.09 .00 & $70^{\circ} 04^{\prime} 08^{\prime \prime N}$ & $171^{\circ} 30^{\prime} 33^{\prime \prime E}$ & 24 & 2.07 & 29.4 & $6.5 \pm 1.5$ \\
\hline 95 & 11.09 .00 & $69^{\circ} 10^{\prime} 33^{\prime \prime} \mathrm{N}$ & $180^{\circ} 00^{\prime} 00^{\prime \prime} \mathrm{E}$ & 30 & -0.46 & 26.7 & $6.7 \pm 1.6$ \\
\hline 104 & 14.09 .00 & $71^{\circ} 00^{\prime} 42^{\prime \prime N}$ & $174^{\circ} 34^{\prime} 29^{\prime \prime} \mathrm{W}$ & 77 & 2.45 & 31.4 & $5.8 \pm 2.5$ \\
\hline 112 & 15.09 .00 & $68^{\circ} 11^{\prime} 20^{\prime \prime} \mathrm{N}$ & $171^{\circ} 43^{\prime} 25^{\prime \prime} \mathrm{W}$ & 47 & 3.05 & 28.8 & $7.5 \pm 2.1$ \\
\hline 115 & 22.09 .00 & & $176^{\circ} 48^{\prime} 50^{\prime \prime} \mathrm{W}$ & 62 & 6.29 & 31.7 & $6.7 \pm 2.0$ \\
\hline 124 & 25.09 .00 & $64^{\circ} 19^{\prime} 42^{\prime \prime} \mathrm{N}$ & $178^{\circ} 42^{\prime} 24 " \mathrm{E}$ & 23 & 4.94 & 22.1 & $9.1 \pm 2.4$ \\
\hline
\end{tabular}

(75\%). Number of tritium nuclei in SNF of atomic icebreaker "Lenin" reactor was calculated in [8]. When SNF protective barriers are destroyed, krypton-85 and tritium will be released to the bottom layer in the form of water or gas oxidized by catalyst in ground deposits. If tritium (or krypton-85) is 


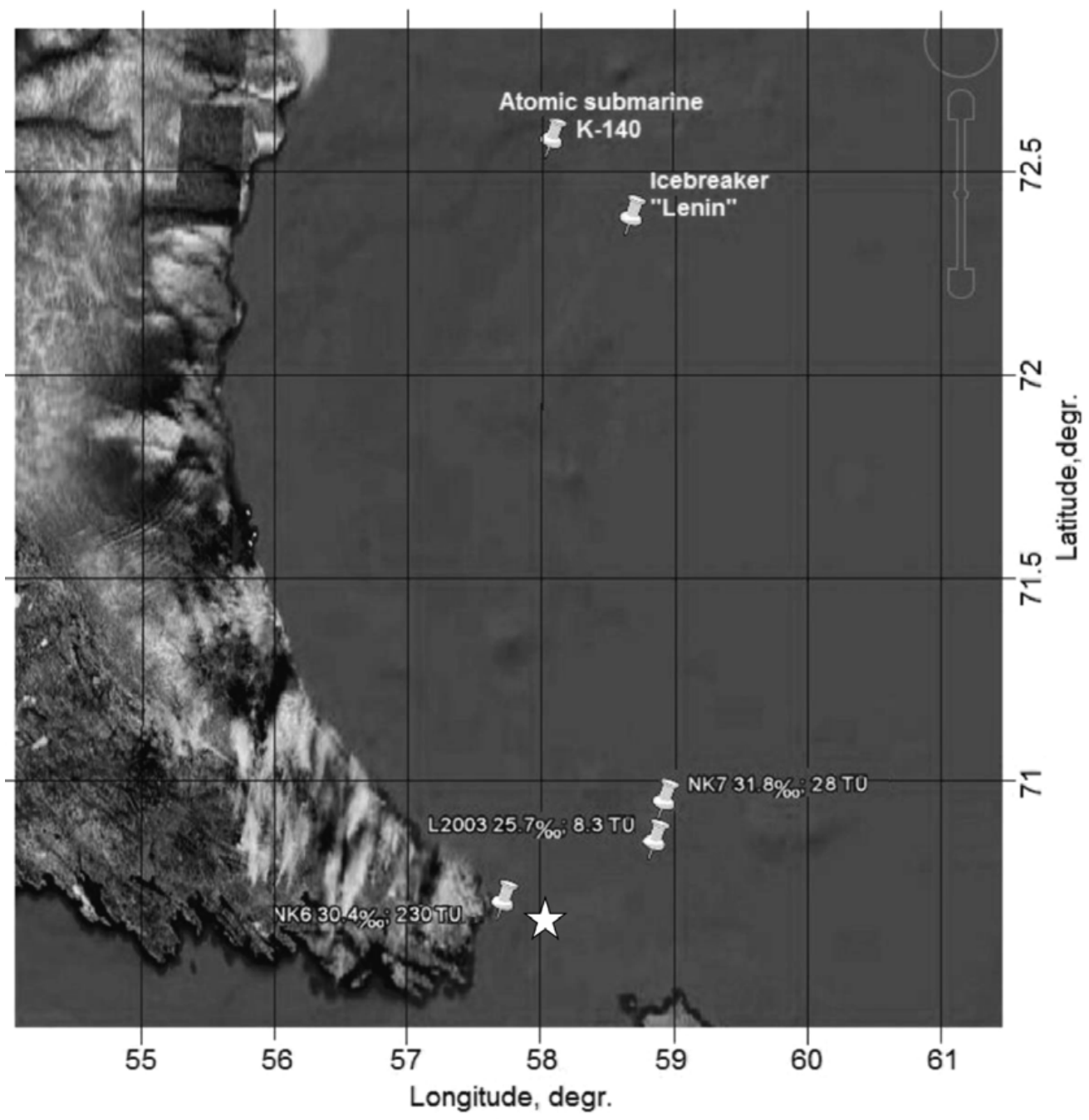

Figure 4. Place of the tritium anomaly in the Kara Sea (station NK 6). Stations numbers, salinity and tritium concentration values are shown.

recognized in water near nuclear objects with SNF at the bottom, then radioactive pollution of the sea environment with fission products has already started.

\subsection{Expedition works}

Background measurements of tritium concentration in water samples were carried out. The samples were selected from the Arctic surface waters along the Northern Seas route during one expedition for the first time. R/V "Nikolay Kolomiytsev" took part in the expedition in 2000 (Fig. 3). Abnormally high tritium concentration was revealed in the samples of surface water from southern part of the Novaya Zemlya Basin in the Kara Sea (more than 200 TU vs. 6-15 TU in other seas of the Russia Arctic shelf!). This anomaly was found at $200 \mathrm{~km}$ to the south of dumping regions of icebreaker "Lenin" and atomic submarine K-140 reactors. So it can be caused by fission products from spent nuclear fuel of these reactors. The abnormal sample was measured by means of two independent methods: 
Table 3. Results of tritium measurements in the Barents and Kara Seas. R/V "Akademik B.Petrov" (2003).

\begin{tabular}{|l|c|c|c|c|c|c|c|}
\hline & & & & & $\mathrm{T}$ & $\mathrm{S}$ & ${ }^{3} \mathrm{H}$ \\
\hline St. No & Date & $\varphi$ & $\lambda$ & Depth $(\mathrm{m})$ & ${ }^{\circ} \mathrm{C}$ & $\%$ & $\mathrm{TU} \pm 2 \sigma$ \\
\hline 1 & 15.08 .03 & $69^{\circ} 52^{\prime} 01^{\prime \prime} \mathrm{N}$ & $36^{\circ} 40^{\prime} 06^{\prime \prime} \mathrm{E}$ & 100 & 11.74 & 34.2 & $5.1 \pm 1.3$ \\
\hline 2 & 16.08 .03 & $70^{\circ} 07^{\prime} 01^{\prime \prime} \mathrm{N}$ & $52^{\circ} 08^{\prime} 09^{\prime \prime} \mathrm{E}$ & 85 & 10.41 & 31.88 & $7.7 \pm 1.3$ \\
\hline $\mathrm{L}$ & 26.08 .03 & $70^{\circ} 49^{\prime} 09^{\prime \prime} \mathrm{N}$ & $58^{\circ} 50^{\prime} 00^{\prime \prime} \mathrm{E}$ & 1 & - & 25.66 & $8.3 \pm 1.1$ \\
\hline 9 & 21.08 .03 & $76^{\circ} 30^{\prime} 01^{\prime \prime} \mathrm{N}$ & $72^{\circ} 02^{\prime} 49^{\prime \prime} \mathrm{E}$ & 140 & -0.03 & 28.53 & $8.8 \pm 1.2$ \\
\hline 7 & 20.08 .03 & $75^{\circ} 33^{\prime} 42^{\prime \prime} \mathrm{N}$ & $73^{\circ} 09^{\prime} 43^{\prime \prime} \mathrm{E}$ & 96 & 7.89 & 8.8 & $17.1 \pm 1.4$ \\
\hline 17 & 20.08 .03 & $71^{\circ} 50^{\prime} 58^{\prime \prime} \mathrm{N}$ & $82^{\circ} 25^{\prime} 23^{\prime \prime} \mathrm{E}$ & 8 & 13.17 & 0.12 & $21.4 \pm 1.5$ \\
\hline
\end{tabular}

scintillation counter with preliminary electrolytic enrichment and low-level background proportional counter (volume was 4 liters). Data obtained during the expedition are presented in Figure 3 and Tables 2 and 3 .

Expedition on R/V "Akademik B. Petrov" was organized in 2003 in order to study state of SNF from nuclear objects at the bottom of the Kara and Barents Seas. The results are presented in Table 3, Fig. 4.

Transportation of tritium by sea current near Novaya Zemlya is possible [11]. Estimations have shown that its velocity at the bottom is about $5 \mathrm{~cm} / \mathrm{s}$ [9]. Time period of 45-50 days must be enough for HTO transportation from dumping region of SNF of icebreaker "Lenin" or Atomic submarine K-140 reactors to the place where tritium anomaly was revealed (station NK 6, Fig. 4).

\section{CONCLUSION}

Experimental research was carried out in order to understand processes which control radioactive pollution of the sea environment. The experimental studies include investigation of fission products release during $\mathrm{UO}_{2}$ corrosion process. Total fission products release from containers with SNF fragment was measured in laboratory during 2800 days of the experiment. Experimental conditions simulate fission products release from the fuel of dumped nuclear icebreaker "Lenin" reactor. Released quantities of Cs-137 from the fuel fragment were about $28 \%$ for pure sea water and about $3 \%$ for water with silt from the Novaya Zemlya Basin. For Kr-85 these values were about 10 and $15 \%$ of the initial accumulated amount. $\mathrm{Kr}-85$ release rate exceeded Cs-137 release rate in few ten times in the beginning of the experiment (first tens of days). However, $\mathrm{Kr}-85$ release reached saturation after 800-900 days of the experiment, while Cs-137 release rate remained almost constant during more than 8 years of the corrosion experiment.

Tritium background measurements were carried out using the samples of Arctic water. The water was sampled from the Arctic surface layer along the Northern Sea cruise during one expedition for the first time. Fission products from spent nuclear fuel were recognized on a shelf of the Arctic as a result of anthropogenic or natural accidents. Abnormal high tritium concentration was discovered in the south of the Novaya Zemlya Basin in the Kara Sea (more than 200 TU vs. 6-15 TU on shelf of other Arctic seas!). The anomaly is located at $200 \mathrm{~km}$ to the south of dumping regions of unloaded reactors from the nuclear icebreaker "Lenin" and atomic submarine K-140. So this anomaly can be caused by release of fission products from SNF of these reactors [11]. The abnormal sample was investigated by two independent methods.

\section{Acknowledgments}

The authors are grateful to $\mathrm{Ph}$ Dr. I. Semiletov (POI FEB RAS Vladivostok) for skilled expedition organization. Work is supported RFBR (Grant 10-05-00366). 


\section{References}

[1] Soyfer V., et al. Meteorol. Gidrol./ No 4 (2006) 59-69.

[2] Soyfer V., Andreev D. Meteorol. Gidrol,/ No.8 (2009) 52-61.

[3] Soyfer V. et al. Radioprotection, Supp. 1, /Volume 40. (EDP Science, 2005) S669-S675.

[4] Soyfer V.Patent, 2010. RU 2382383 C1. Bull.5.

[5] Soyfer V. et al., in Tritium researches for natural waters in Russia (GEOS , Moscow, 2008), 286 p. (in Russian),

[6] Albenesius E. Phys. Rev. Sci., /Volume 3, No. 6 (1959) 274-275.

[7] Albenesius E.and Ondrejcin E., Nucleonics, Volume 18, No. 9 (1960) 100.

[8] Timms S.J., et al. in Proc.Workshop on Modelling the dispersion of Nuclear Contaminants in the Arctic Seas eds by R.Preller and R. Edson (Naval Research Laboratory, 1995) pp. 268-293.

[9] Pavlov V.K., et al. In Proc. AARI, 442, 180 - 190 (1999, in Russian).

[10] Soyfer V., et al., Oceanology. /Volume 50, No 4 (2010) 636-648.

[11] N. Korchagin, A. Monin, in Mesooceanology (Nauka, Moscow, 2008) pp. 29-46, (in Russian). 